\title{
PEMBERDAYAAN MASYARAKAT PADA HOME INDUSTRY SIRUP MARKISA DI DESA SUKAMANTRI KABUPATEN BOGOR
}

\section{Community Empowerment In Passion Fruit Syrup Home Industry In Sukamantri Village, Bogor Regency}

\author{
Nadia Inayah ${ }^{1^{*}}$, Muhtadi ${ }^{1}$ \\ ${ }^{1}$ Program Studi Pengembangan Masyarakat Islam Fakultas Dakwah dan IImu \\ Komunikasi Universitas Islam Negeri Syarif Hidayatullah Jakarta \\ *Email: crossa25.ni@gmail.com
}

\begin{abstract}
Community empowerment activities are carried out at the passion fruit syrup home industry located in Sukamantri Village, Bogor Regency. The purpose of this empowerment activity is to help the owner so that his business increases and the community becomes more productive by carrying out empowerment activities. There are 4 activities in the empowerment of passion fruit syrup, namely: 1) Seeing potential problems, 2) Planning activities, 3) Carrying out empowerment activities, 4) Program evaluation, 5) Analyzing supporting and inhibiting factors. The method used is a qualitative approach, with interviews, observations, and documentation, and uses triangulation techniques. There are 5 participants in this activity, 3 housewives, and 2 residents who have not worked (unemployed). The results of this study are to see that the potential in this village has a fairly large plantation area of 1,760,000 hectares and has cool air and high rainfall which is very suitable for cultivating passion fruit, the intended location is the passion fruit syrup home industry owned one of the farmers who uses his land to cultivate passion fruit into passion fruit syrup and can open job vacancies for the community. Planning and implementation in this activity was carried out in 4 meetings. This activity is carried out at the home of the business owner, every Sunday, at 12.30-15.30. In the evaluation of passion fruit syrup community empowerment activities, it has shown a positive impact for participants, this can be seen from the good response of all participants in the empowerment process. The supporting factors in this activity are qualified human resources, as well as production tools and materials provided by the business owner, and the inhibiting factor in this activity is the erratic growth of passion fruit. After this activity, the participants became employees of Mr. Muiz's passion fruit syrup home industry.
\end{abstract}

Keywords: empowerment, home industry, passion fruit syrup

\begin{abstract}
ABSTRAK
Kegiatan pemberdayaan masyarakat dilakukan pada home industry sirup markisa yang terletak di Desa Sukamantri Kabupaten Bogor. Tujuan kegiatan pemberdayaan ini adalah untuk membantu owner agar usahanya meningkat dan masyarakat menjadi lebih produktiv dengan melakukan kegiatan pemberdayaan. Ada 4 kegiatan dalam pemberdayaan sirup markisa, yaitu: 1) Melihat adanya potensi permasalahan, 2) Merencanakan Kegiatan, 3) Melaksanakan kegiatan pembedayaan, 4) Evaluasi program, 5) Menganalisis faktor pendukung dan penghambat. Metode yang digunakan melalui pendekatan kualitatif, dengan wawancara, observasi, dan dokumentasi, serta menggunakan teknik triangulasi. Partisipan dalam kegiatan ini ada 5 orang, 3 lbu Rumah Tangga, dan 2 warga yang belum bekerja (pengangguran). Hasil dari penelitian ini adalah melihat bahwa potensi di Desa ini memiliki lahan perkebunan yang cukup luas yaitu seluas 1.760.000 hektar dan memiliki hawa yang sejuk dan curah hujan yang cukup tinggi sangat cocok untuk membudidaya buah markisa. lokasi yang dituju yaitu home industry sirup markisa milik salah satu petani yang memanfaatkan lahan nya untuk membudidayakan buah markisa menjadi produk sirup markisa serta dapat membuka lowongan pekerjaan bagi masyarakat. Perencanaan dan pelaksanaan dalam kegiatan ini dilakukan sebanyak $4 x$ pertemuan. Kegiatan ini dilaksanakan di rumah pemilik usaha tersebut, pada setiap hari minggu, pukul $12.30-15.30$. Pada Evaluasi kegiatan Pemberdayaan masyarakat sirup markisa sudah memperlihatkan dampak yang positif bagi partisipan, Hal ini dilihat dari respon yang baik dari semua partisipan dalam proses pemberdayaan. Adapun faktor pendukung dalam kegiatan ini yaitu Sumber Daya Manusia SDM yang mumpuni, serta alat dan bahan produksi disediakan oleh pemilik usaha, dan
\end{abstract}


faktor penghambat dalam kegiatan ini adalah pertumbuhan buah markisa yang tidak menentu. Setelah adanya kegiatan ini, para partisipan menjadi karyawan di home industry sirup markisa milik Bapak Muiz.

Kata Kunci: home industry, pemberdayaan, irup markisa

\section{Pendahuluan}

Pada Permendagri RI Nomor 7 Tahun 2007 Pasal 1 ayat 8 bahwa, pemberdayaan masyarakat adalah sebuah strategi yang digunakan dalam pembangunan masyarakat sebagai upaya untuk mewujudkan kemampuan dan kemandirian dalam kehidupan bermasyarakat, berbangsa, dan bernegara. Bukan hanya konsep atau teori saja, pemberdayaan masyarakat harus di aplikasan dengan beberapa tahapan. Menurut Sudjana dalam Hatimah (2010: 3.22) tahap-tahap pemberdayaan meliputi perencanaan, pelaksanaan, dan evaluasi.

(1980) Menurut rumusan Havelock pemberdayaan masyarakat seperti perubahan dalam berinovasi yang terencana bisa disebut sebagai Agen of Change, dan pemberdayaan masyarakat menurut Depdiknas (2003) adalah proses, cara ataupun perbuatan membuat berdaya yakni kemampuan bertindak yang berupa upaya. Dalam konteks pemberdayaan, mahasiswa bekerja sama dengan Agen lainnya untuk memberikan fasilitas serta membantu meningkatkan produktivitas masyarakat seperti Ibu Rumah Tangga (IRT) (Diwanti and Dharma, 2019)

Desa Sukamantri, Kabupaten Bogor merupakan wilayah yang terletak di kaki Gunung Salak dan mempunyai alam yang asri dan sejuk, serta banyak sekali pepohonan yang tumbuh karena berada di dataran yang tinggi. Masyarakat nya mayoritas bermata pencaharian sebagai petani. Namun, seiring berjalannya waktu masyarakat beralih profesi menjadi buruh harian lepas dan bahkan ada yang menganggur serta merantau ke kota karena banyak lahan persawahan yang sudah digarap menjadi perumahan atau pembangunan lainnya. Dengan hal ini menjadi sebuah problematika tersendiri bagi masyarakat desa Sukamantri dari segi mata pencaharian. Dari data yang ditemukan, menurut website resmi Desa Sukamantri jumlah penduduk desa tersebut 17.878 jiwa, terdapat jumlah pekerja buruh harian lepas dan karyawan swasta yang paling didominasi, yaitu 2.156 jiwa untuk karyawan swasta, 1.484 jiwa untuk buruh harian lepas. Namun, IRT dan yang belum bekerja pun sangat banyak, total yang belum bekerja ada 4.228 jiwa, dan IRT berjumlah 4.283 jiwa. Dari data tersebut jumlah IRT dan pengangguran adalah yang paling banyak jumlahnya jika dibandingkan dengan pekerjaan lainnya seperti karyawan swasta. buruh harian lepas, dll. Dengan adanya permasalahan seperti ini peran seorang pemberdaya sangat dibutuhkan untuk membuka lowongan pekerjaan baik itu untuk yang belum bekerja maupun IRT.

Pemberdayaan harus dilakukan guna mensejahterakan masyarakat, baik itu dari kegiatan pemerintah desa ataupun sekelompok masyarakat yang melakukan pemberdayaan untuk warga sekitar. Seperti adanya petani yang memberdayakan masyarakat di wilayah RW 01 Desa Sukamantri dengan membuka usaha home industry sirup markisa untuk para lbu rumah tangga dan warga yang sedang membutuhkan pekerjaan. Banyak petani yang menyewa dan menggarap tanah di atas lahan kebun percobaan IPB Desa Sukamantri yang luasnya 40 hektare, termasuk petani ini ikut menyewa dan menggarap di atas lahan tersebut seluas 2000 meter persegi. Lahan yang 
disewakan diberi nama oleh masingmasing para penyewa, seperti "Kebun Asri Flora". Penyewa Kebun Asri Flora ini adalah warga asli desa Sukamantri dan bekerja sebagai pengusaha sekaligus petani. Kebun Asri Flora ditanami berbagai macam tumbuhtumbuhan dan tanam-tanaman seperti pohon Markisa, durian, jambu kristal, pisang, mangga, sawo, sirsak, dll, yang hasil kebunnya biasanya di jual ke pasar. Namun, dengan adanya pandemik covid-19 ini penyewa Kebun Asri Flora terkena dampaknya dan hasil penjualan kebun tidak stabil. Pada akhirnya Petani tersebut membuat inovasi atau terobosan untuk mengolah hasil panennya menjadi usaha baru agar mempertahankan ekonomi keluarganya. Usahanya adalah sirup markisa, usaha ini baru dirintis 1 tahun yang lalu dan belum berkembang pesat karena masih diproduksi sendiri, meskipun masih merintis, respon warga terhadap rasa sirup markisa ini cukup memuaskan hati serta dengan banyaknya masukan dari masyarakat khususnya lbu rumah tangga RW 01, mereka menyarankan agar membuka home industry sebagai wadah mencari nafkah mereka. Mahasiswa Pengembangan Masyarakat Islam ikut membantu pemilik usaha untuk meningkatkan usaha dan produktivitas masyarakat melalui kegiatan pelatihan pembuatan kemasan produk dan strategi promosi. Dengan adanya wadah pemberdayaan seperti ini diharapkan masyarakat lebih produktif dan meningkatkan ekonomi sekitar.

Buah markisa mempunyai khasiat yang sangat bagus untuk kesehatan, salah satunya yaitu kaya akan vitamin $\mathrm{C}$ dan dapat meningkatkan daya tahan tubuh. Selain markisa bisa dijadikan sirup, buah markisa pun dapat dimanfaatkan untuk pembuatan olahan markisa lainnya, dan masih banyak manfaat lainnya bagi manusia. Hal tersebut sejalan dengan penelitian Jasminarni (2019) menyatakan pengembangan budidaya markisa dan pengolahannya merupakan usaha jenis agroindustry yang banyak memiliki potensi besar untuk dikembangkan, markisa sendiri banyak memberikan manfaat bagi manusia, isi buahnya bisa dijadikan sirup, biji markisanya yang telah dikeringkan bisa dijadikan minyak atsiri, serta kulitnya dapat dijadikan sebagai makanan ternak setelah melewati fase fermentasi, selain itu biji nya bisa dijadikan bibit markisa untuk dibudidayakan kembali. Dapat dibayangkan betapa tingginya nilai ekonomis tanaman markisa ini.

Pada penelitian Jasminarni (2019) Buah markisa dengan rasa yang asam diolah menjadi dodol dan sirup markisa, serta dapat dijadikan oleh-oleh bagi wisatawan yang berkunjung ke tempat wisata. Oleh karena itu dengan adanya penelitian ini diharapkan dapat melakukan diversifikasi produk olahan sirup markisa dari segi promosi danpengemasannya agar home industry sirup markisa semakin berkembang.

\section{Metode}

Penelitian ini menggunakan pendekatan kualitatif. Tujuan dari penelitian ini adalah untuk meningkatkan mitra usaha Kebun Asri Sirup Markisa berkembang, dan meningkatkan produktivitas masyarakat di wilayah RW 01 Desa Sukamantri Kabupaten Bogor. Penelitian ini mendapatkan data dengan menggunakan teknik obsevasi, wawancara, dan dokumentasi. Observasi penelitian ini melihat kondisi lingkungan, melihat sarana prasana yang ada di home industry tersebut, dan kegiatan program yang sudah direncanakan. Kegiatan wawancara ini dilakukan kepada Pemilik usaha home industry sirup markisa, 3 lbu Rumah Tangga dan 2 warga yang belum bekerja.Penelitian ini juga menggunakan teknik triangulasi (FAUZIYAH, 2016), untuk mendapatkan keabsahan data, dengan cara mengecek data kepada sumber yang 
sama pada teknik yang berbeda, dan teknik yang digunakan yaitu obervasi, wawancara, dan dokumentasi.

Metode pengumpulan data dengan observasi, wawancara dan penyebaran kuesioner. Kuesioner yang digunakan sudah dilakukan uji coba terlebih dahulu kepada mahasiswa pascasarjana penyuluhan pembangunan yang dianggap memahami objek penelitian. Hasil analisis uji kuesioner disimpulkan bahwa jumlah pernyataan yang valid sebanyak 21 dari 28 pernyataan yang ada. Dari 7 pernyataan yang tidak valid tersebut dilakukan perbaikan kalimat (tata bahasa) agar menjadi lebih jelas dan mudah dipahami responden. Adapun hasil uji reliabilitas kuesioner penelitian menunjukkan hasil bahwa kuesioner penelitian reliabel dengan nilai koefisien Cronbach Alpha sebesar 0,732 .

Data inti penelitian dianalisis menggunakan statistik deskriptif untuk mendeskripsikan karakteristik dan persepsi masyarakat Desa Tegalwaru, dan statistik inferensial (korelasi rank Spearman) untuk menganalisis faktorfaktor yang berhubungan dengan persepsi masyarakat tentang Desa Wisata Tegalwaru.

\section{Hasil dan Pembahasan}

Hasil Penelitian ini menggunakan pendekatan kualititif, dari hasil penelitian yang dilakukan data yang didapat melalui observasi, wawancara, maupun dokumentasi terhadap informan yang diteliti maka pembahasan ini meliputi 3 kegiatan pokok, yang pertama perencanaan, yang kedua pelaksanaan, dan yang ketiga evaluasi program kegiatan. Pemberdayaan ini dilaksanakan di wilayah rw 01 Desa Sukamantri, dilakukan oleh peneliti dan pelaku usaha sirup markisa kebun asri yang di pimpin oleh Bapak Muiz sebagai fasilitator, disini peneliti bersama owner melakukan kegiatan pelatihan serta mendampingi masyarakat agar dapat membuat produk sirup markisa dan kemudian di jual untuk menambah pendapatan masyarakat tersebut. Berikut kegiatan dan tahapan dalam pemberdayan masyarakat pada home industry sirup markisa kebun asri di Desa Sukamatri Kabupaten Bogor:

\section{A. Adanya potensi permasalahan di tengah masyarakat}

Menurut website resmi

Desa Sukamantri, Desa ini memiliki jumlah penduduk 17.878 ribu jiwa di 15 RW dan 67 RT. Dilihat dari RKPDes Desa Sukamantri, tercatat sumber potensi desa kebanyakan bersumber dari lahan-lahan pertanian dan Lahan perkebunan dengan luas 1.760 .000 hektar,serta jenis pekerjaan di Desa Sukamantri ada 0,60 persen adalah petani juga buruh tani (Humaira, Maad and Andriyanti, 2019). IRT dan yang belum bekerja pun sangat banyak, total yang belum bekerja ada 4.228 jiwa, dan IRT berjumlah 4.283 jiwa. Dari data website Desa tersebut jumlah IRT serta pengangguran adalah yang paling banyak jumlahnya jika dibandingkan dengan pekerjaan lainnya, dapat diartikan bahwa di Desa ini masih banyak masyarakat yang belum bekerja, oleh karena itu peran pemberdaya sangat dibutuhkan untuk membuka lowongan pekerjaan.

Adapun potensi yang bisa digali di Desa Sukamantri, Desa ini memiliki hawa yang sejuk dan curah hujan yang cukup tinggi sangat cocok untuk membudidaya buah markisa. Menurut Penelitian Jasminarni (2019), tanaman buah markisa sangat cocok ditanam di iklim yang sejuk dan curah hujan yang cukup tinggi. Pada penelitian kali ini, lokasi yang dituju yaitu home industry sirup markisa milik salah satu petani yang memanfaatkan lahan nya untuk membudidayakan buah markisa menjadi produk sirup markisa. Buah markisa kaya akan manfaat, dan buah markisa dapat diolah apa saja, seperti dodol, selai, dll. Oleh karena itu, Pemilik home industry sirup markisa dapat 
membuka lowongan pekerjaan bagi masyarakat khususnya IRT dan pengangguran untuk membantu dalam memperbaiki ekonomi keluarga. (Suminartini and Susilawati, 2020).

\section{B. Perencanaan Pemberdayaan}

Kegiatan

Sebelum merencanakan kegiatan, peneliti mendatangi tempat tinggal rumah pemilik usaha sirup markisa untuk mencari info mengenai usaha nya yang baru dirintis 1 tahun yang lalu dengan mewawancarai beberapa pertanyaan dan meminta izin untuk membuat kegiatan pelatihan dan pendampingan produk sirup markisa, serta mendapat respon dan antusias yang baik. Sasaran pemberdayaan ini yaitu Ibu Rumah Tangga dan warga yang belum bekerja (pengangguran).

Perencanaan dalam suatu kegiatan sangatlah penting, oleh karena itu rencana perlu dibuat agar pada saat kegiatan berjalan dengan lancar. Pada rencana kegiatan pemberdayaan ini setelah melakukan pembicaraan dengan pemilik usaha yang pertama dilakukan yaitu:

1) Mengadakan sosialisasi yang bersifat ketuk pintu tetangga atau dari rumah ke rumah untuk mengajak masyarakat membuat sirup markisa agar bisa di jual,

2) Peneliti mewawancarai pemilik usaha sirup markisa terkait proses pembuatan sirup markisa. Menurut pemilik usaha ini "pembuatan sirup markisa cukup mudah, tinggal kupas buah markisa, pisahkan biji dengan kulitnya, masukkan air kedalam wadah yang sudah ada biji markisanya, kemudian saring, lalu masak hingga matang, yang terakhir jika sudah dingin, langsung dikemas." Dengan demikian pada saat pelaksanaan, peneliti nantinya dapat mendampingi partisipan.

3) Pelaksanaan dilakukan 4x pertemuan, di rumah pemilik usaha home industry, pada setiap hari minggu pukul 12.30 15.30

- Pertemuan pertama membuat sirup markisa.

- Pertemuan kedua dan ketiga membuat sirup markisa serta memasarkan produk,

- Pertemuan keempat mengevaluasi program.

Partisipan berjumlah 5 orang, 3 Ibu Rumah Tangga, dan 2 laik-laki yang belum mendapatkan pekerjaan (pengangguran). Tak lupa pula dalam penelitian ini mengobservasi faktor pendukung dan penghambat pemberdayaan masyarakat pada home industry sirup markisa. Selain itu sumber dana dalam kegiatan pemberdayaan sangatlah penting, dan pada pemberdayaan ini mulai dari menyediakan alat dan bahan murni biaya pribadi pemilik usaha home industry, perencanaan dalam metode pemberdayaan masyarakat harus direncanakan dengan baik. Pendapat Novitasi dan Sugito (2018: 99) tahap perencanaan adala tahap dasar untuk mengimplementasi tindakan.

Jadwal pelatihan pembuatan sirup markisa yaitu pada hari minggu, pukul 12.30 - 15.30 di rumah Bapak Muiz selaku pemilik usaha home industry. Media yang digunakan dalam pembuatan sirup markisa adalah markisa yang sudah matang, dan gula pasir, serta alat produksinya masih terbilang sederhana, seperti alat penyaringan, baskom, dan panci milik Bapak Muiz. Untuk teknik pemasaran, produk di pasarkan di wilayah RW 01, dan di sebar ke media sosial melalui partisipan. Metode pada pelatihan pembuatan sirup markisa, yaitu pendampingan dan diskusi.

\section{Pelaksanaan kegiatan pemberdayaan masyarakat pada home industry sirup markisa \\ Pertemuan pertama (Pelatihan Sirup Markisa)}

Pada pertemuan pertama, pelatihan ini dilaksanakan pada hari 
minggu pukul 12.30 - 15.20 di rumah pemilik usaha, dengan partisipan yang hadir berjumlah 5 orang. Pada pertemuan pertama, pemilik usaha menerangkan dan melatih para partisipan dalam membuat sirup markisa. Buah markisa yang digunakan berjumlah 20 buah, dan menghasilkan 40 botol berukuran $250 \mathrm{ml}$. Berikut tahapan pembuatan sirup markisa berdasarkan hasil diskusi dengan pemilik usaha:

1) Mencuci buah markisa dibilas dengan air bersih

2) Membelah dua buah markisa, lalu pisahkan isi buahnya dari kulit markisa

3) Biji buah markisa ditempatkan pada wadah yang bersih dan ditambahkan air 10 liter lalu aduk hingga warna nya tercampur rata

4) Memisahkan biji buah markisa dengan metode penyaringan, air yang sudah disaring dimasukkan kedalam panci yang cukup besar

5) Menghidupkan kompor dengan suhu sedang

6) Setelah mendidih, masukan gula sebanyak 2 sampai $3 \mathrm{~kg}$ sedikit demi sedikit lalu diaduk dengan konstan

7) Matikan kompor setelah gula larut dan tunggu hingga suhu panasnya menurun, lalu adukaduk perlahan

8) Setelah suhu kurang lebih 30 derajat, air sirup markisa dimasukkan kedalam kemasan, dan di simpan di kulkas sampai dingin

9) Sirup markisa sudah siap di produksi.

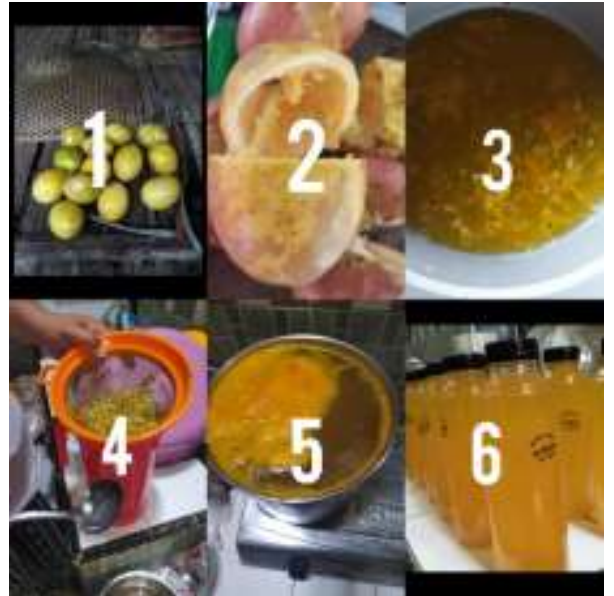

Gambar 1. Tahap pembuatan

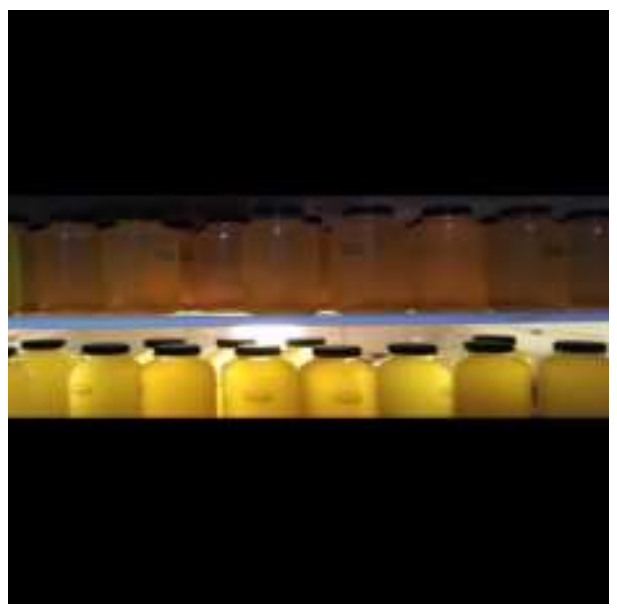

Gambar.2 Produk sirup markisa

\section{Pertemuan kedua (Pelatihan pembuatan sirup markisa)}

Pada Pertemuan kedua, pelatihan ini dilaksanakan pada hari minggu pukul 12.30 - 15.20 di rumah pemilik usaha, dan partisipan yang hadir berjumlah 5 orang. Buah markisa yang digunakan berjumlah 40 buah, menghasilkan 80 botol berukuran $250 \mathrm{ml}$, dan air yang digunakan 20 liter kemudian disaring, direbus dan dicampurkan gula sebanyak 4 kg. Pertemuan kedua ini, para partisipan terlibat dalam proses pembuatan sirup markisa maupun diskusi. Pada saat menunggu sirup markisa matang, para partisipan dengan pemilik usaha saling berdiskusi terkait kemasan produk sirup markisa yang masih terbilang sepi dan perlu diperbaiki 
agar konsumen lebih tertarik. Salah satu partisipan tersebut menyarankan untuk merubah atau mengganti kemasan produk sirup markisa. Setelah berdiskusi, semua yang ada di forum diskusi tersebut menyepakati bahwa logo atau design stiker harus dirubah, dan pemilik usaha meminta bantuan kepada tempat percetakan untuk membuatkan logo tersebut. Label atau logo produk mempunyai fungsi dan manfaat sebagai identitas dan dapat meningkatkan nilai produk itu sendiri. Selain itu, label atau logo dapat menjadi pengingat bagi para konsumen atau pelanggan sehingga dapat meingkatkan repeat order (Fay, 1967)

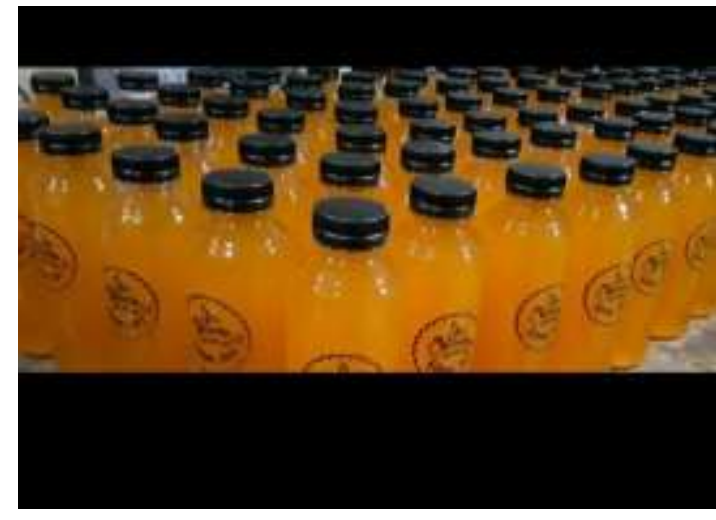

Gambar 3. Produk sirup markisa dengan kemasan yang diperbaharui

\section{Pertemuan Ketiga}

Setelah pelatihan pembuatan sirup markisa di pertemuan ketiga, pemilik usaha, memberikan pelatihan bagaimana cara memasarkan dan mempromosikan produk, serta berdiskusi terkait kemasan produk perlu dikembangkan kembali. Dari hasil penelitian, sebelum adanya kegiatan pemberdayaan ini, produksi sirup markisa hanya untuk pesanan saja, hal ini menyebabkan volume penjualan tidak pasti dan akibatnya omset atau income usaha menjadi tidak pasti. Namun dengan adanya kegiatan pemberdayaan ini peneliti dan pemilik usaha banyak berdiskusi untuk memasarkannya agar produk sirup markisa dapat berkembang. Pada akhirnya, fasilitator memberikan arahan terkait pemasaran kepada partisipan memasarkan produk sirup markisa dengan memanfaatkan media sosial dan dari mulut ke mulut, warga menjadi tau bahwa ada yang menjual produk sirup markisa ini. Saat ini sirup markisa kebun asri sudah menembus kafe-kafe dan koperasi di luar wilayah rw 01 serta sudah mulai dikenal oleh sebagian masyarakat rw 01 Desa Sukamantri Kabupaten Bogor. Dengan hal ini usaha mikro dapat terbangun, perlu diketahui bahwa usaha mikro tidak bisa dipandang remeh, karena usaha mikro sangat berperan penting dalam meningkatkan ekonomi masyarakat. (Suprojo and Fithriana, 2017)

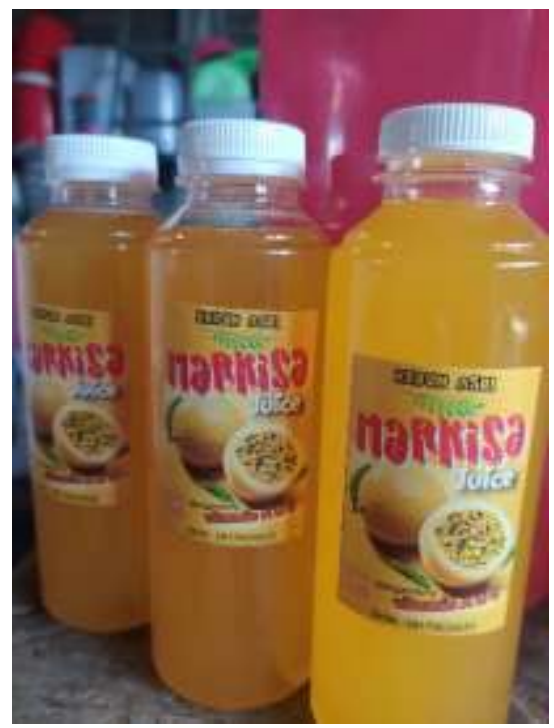

Gambar 4. Kemasan terbaru

Selain itu teknik pemasaran yang digunakan dalam penjualan produk ini yaitu dengan membanting harga, karena mengingat banyak pesaing diluaran sana. Harga yang terjangkau menjadi nilai tambah bagi produk sirup markisa ini, dan harga per botol berukuran $250 \mathrm{ml}$ di bandrol seharga Rp 5.000 saja. Kemudian, pertemuan keempat yaitu mengevaluasi kegiatan pemberdayaan masyarakat pada home industry sirup markisa di Desa Sukamantri Kabupaten Bogor. Dalam strategi pemasaran inovasi sangat penting dilakukan dan untuk meningkatkan eksistensi produk, 
pemasaran dilakukan dengan fokus kepada produknya dikemas dengan baik, harganya terjangkau agar bersaing dengan produk lainnya, kemudian promosi di media sosial sangat diperlukan, dan mengirim produk ke kafe-kafe serta warung setempat. Hal ini diharapkan penjualan dapat meningkat disetiap bulannya. (Rohmani, Yugatama and Prihapsara, 2018)
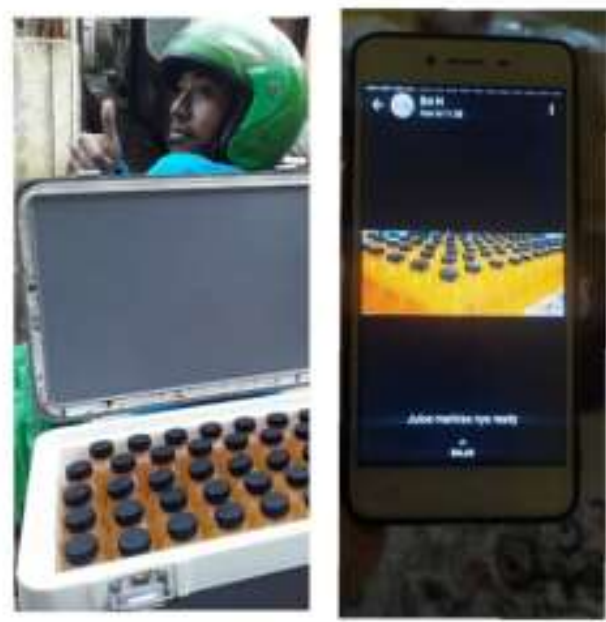

Gambar 5.Proses pemasaran produk

\section{Evaluasi Program}

Adanya evaluasi bertujuan untuk mengetahui apakah kegiatan yang sudah dilaksanakan mendapatkan outcome atau dampak yang positif, kemudian apakah kegiatan tersebut sudah efektif dan efesien sesuai rencana atau belum. Jika evaluasi dalam suatu kegiatan tersebut menimbulkan dampak negatif maka kegiatan harus dihentikan. Sesuai dengan pendapat siswanto (2011:9293) tingkatan suatu evaluasi dan dampak pada kegiatan bertujuan untuk mengukur outcome maupun dampaknya. Kegiatan yang di evaluasi harus berdampak positif bagi perkembangan suatu kegiatan. (Faiqoh, 2019)

Pada Evaluasi kegiatan Pemberdayaan masyarakat sirup markisa sudah memperlihatkan dampak yang positif bagi partisipan, kemudian kegiatan yang di evaluasi yaitu meliputi proses pembuatan dan pelatihan sirup markisa, kemudian proses pelatihan pemasaran oleh fasilitator berjalan cukup baik. Hal ini dilihat dari respon yang baik dari semua partisipan dalam proses pemberdayaan. Menurut partisipan yang sehari-harinya menjadi lbu rumah tangga, dengan mengikuti kegiatan pelatihan pembuatan sirup markisa ini merasa jauh lebih produktif. Begitupun dengan partisipan lainnya yang blm mendapatkan pekerjaan (pengangguran), merasa sangat senang karena mempunyai kegiatan baru yang positif.

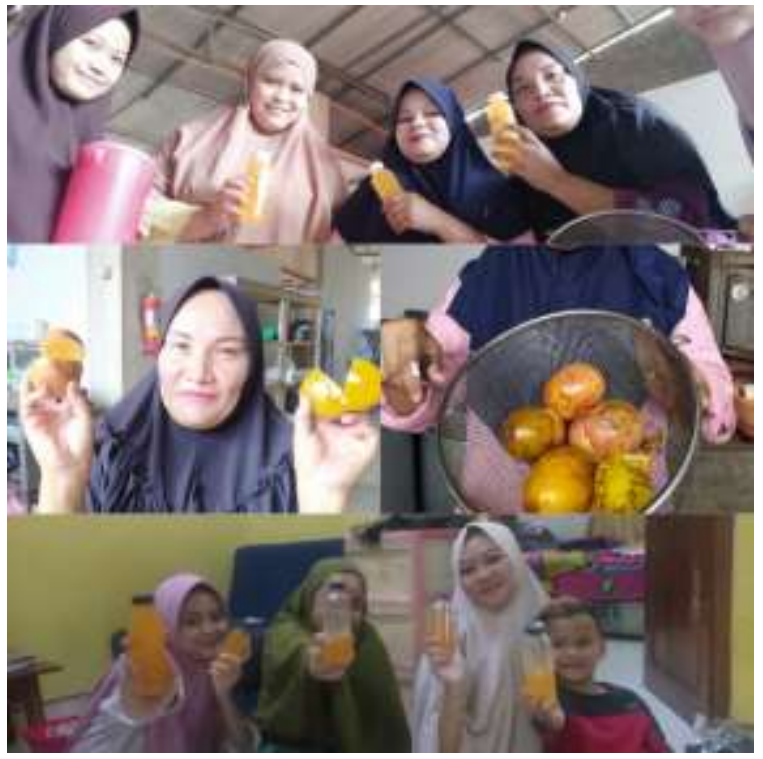

Gambar 6. Kegiatan partisipan pada saat mengolah sirup markisa

\section{E. Faktor Pendukung Pemberdayaan masyarakat pada home industry sirup markisa di Desa Sukamantri Kabupaten Bogor}

1) Faktor Sumber Daya Manusia SDM yang mumpuni menjadi faktor pendukung dalam kegiatan ini, karena para partisipan yang sudah berpartisipasi cukup mampu dan tanggap pada saat pembuatan sirup markisa, hal ini sesuai dengan pendapat (Rahimian, 2015: 664) bahwa pengembangan SDM cocok dalam pembedayaan. (Faiqoh, 2019)

2) Faktor Ekonomi, Lima partisipan dalam kegiatan pemberdayaan ini ikut 
dan menjadi karyawan "kebun asri sirup markisa". 2 partisipan laki-laki bekerja di kebun untuk membantu Bapak Muiz dan mengurus bibit-bibit markisa, kemudian kemudian 3 partisipan lbu rumah tangga untuk memproduksi sirup markisa dirumah Bapak Muiz sebagai pemilik usaha ini.

3) Harga yang terjangkau, Sirup markisa perbotol berukuran $250 \mathrm{ml}$ dijual dengan harga $\mathrm{Rp} 5.000$ saja, dengan harga yang cukup terjangkau, sirup markisa ini dapat bertahan bahkan semakin berkembang, dan harga ini bisa dijangkau oleh semua kalangan masyarakat.

\section{F. FaktorPenghambat Pemberdayaan masyarakat pada home industry sirup markisa di Desa Sukamantri Kabupaten Bogor}

Faktor penghambat dalam kegiatan ini adalah pertumbuhan buah markisa yang tidak menentu. Pada pertemuan pertama dan kedua buah markisa yang sudah matang cukup banyak, ada 20 sampai 40 buah markisa yang dipanen dikebun, kemudian di olah menjadi sirup markisa. Namun, terjadi kendala dan hambatan pada pertemuan ketiga karena kehabisan stok buah markisa, hanya ada 5 buah markisa saja yang matang dan kemudian hasil olahan sirup markisa terhitung 10 botol saja.

\section{Simpulan}

Dari hasil kegiatan pelatihan pembuatan sirup markisa yang telah dilaksanakan di Desa Sukamantri Kabupaten Bogor, dapat disimpulkan bahwa penjualan sirup markisa menjadi meningkat dan sudah dipasarkan ke beberapa kafe, serta masyarakat yang ada di wilayah tersebut menjadi lebih produktif dengan melakukan kegiatan pelatihan pembuatan sirup markisa ini. Proses pemberdayaan yang dilakukan yaitu dengan melakukan teknik perencanaan, pelaksanaan, dan evaluasi.

$\begin{array}{llr}\text { Perencanaan dan } & \text { dan } \\ \text { dalam kegiatan ini }\end{array}$

dilakukan sebanyak 4x pertemuan. pertemuan pertama melakukan pelatihan pembuatan sirup markisa, dan pertemuan kedua melakukan pelatihan serta diskusi terkait design kemasan, lalu pada pertemuan ketiga melakukan pelatihan pembuatan sirup, serta pelatihan pemasaran produk. Pertemuan terakhir melakukan evaluasi dan pada pertemuan terakhir, partisipan merespon baik dengan adanya kegiatan pelatihan ini. Kegiatan ini dilaksanakan di rumah pemilik usaha tersebut, pada setiap hari minggu pukul $12.30-15.30$. Adapun faktor pendukung dalam kegiatan ini yaitu Sumber Daya Manusia yang mumpuni, serta alat dan bahan produksi yang disediakan oleh pemilik usaha. Untuk faktor penghambat dalam kegiatan ini adalah pertumbuhan buah markisa yang tidak menentu. Setelah adanya kegiatan ini, para partisipan menjadi karyawan di home industry sirup markisa milik Bapak Muiz.

\section{Ucapan Terima Kasih}

Pada penelitian ini, penulis mengucapkan banyak terima kasih kepada Kepala Jurusan (Kajur) Program studi Pengembangan Masyarakat UIN Syarif Hidayatullah Jakarta karena telah membimbing dan memberikan dukungan terhadap penelitian ini. Selain itu penulis juga mengucapkan banyak terima kasih kepada Pemilik Usaha home industry sirup markisa yang sudah memberikan dukungan serta membantu menyukseskan kegiatan pemberdayaan sirup markisa, dan juga telah menyediakan alat dan bahan maupun waktu dalam pembuatan sirup markisa, dan penulis mengucapkan banyak terima kasih kepada partisipan yang sudah hadir dalam kegiatan ini.

\section{Daftar Pustaka}

Buah, P. 'Pengolahan Buah Markisa menjadi Sirup', pp. 0-2.

Diwanti, D. P. and Dharma, A. F. (2019) 'Pengembangan Potensi 
Masyarakat Bangunmulyo Melalui

Program I-Createdi

(Inovasi,Kreatif Dan Mandiri)

Home Industri Salak Pondoh',

Martabe: Jurnal Pengabdian Kepada Masyarakat, 2(2), p. 62. doi: 10.31604/jpm.v2i2.62-66.

Faiqoh, P. (2019) 'Pemberdayaan Perempuan Melalui Home Industri Batik Sekar Jagad Di Dusun Tanuraksan Desa Gemeksekti Kabupaten Kebumen', Pendidikan Luar Sekolah Fakultas IImu Pendidikan Universitas Negeri Semarang, 22(1), pp. 1-75.

FAUZIYAH, A. (2016) 'Pemberdayaan Masyarakat Melalui Kegiatan Home Industry Kerupuk Ikan Di Desa Srowo Kecamatan Sidayu Kabupaten Gresik', J+Plus Unesa, 5(2), pp. 1-9.

Fay, D. L. (1967), Angewandte Chemie International Edition, 6(11), 951952., 2(2), pp. 135-142.

Jambi, U. (2013) 'PENDAPATAN KELUARGA Jasminarni, Suandi, Trias Novita dan Evita', pp. 47-49.

Nuraisyah, F. and Ruliyandari, R. (2020) 'PEMBERDAYAAN KELOMPOK IBU RUMAH TANGGA: PELATIHAN PEMBUATAN SABUN DARI MINYAK GORENG
BEKAS MENJADI HOME', 4(2), pp. 2019-2021.

Rohmani, S., Yugatama, A. and Prihapsara, F. (2018) 'Inovasi Minuman Sehat Berbahan Kedelai dalam Upaya Pemberdayaan Masyarakat melalui Wirausaha di Kabupaten Sukoharjo Innovations Healthy Drinks in Source of Soybean in Community Empowerment through Entrepreneurship in Sukoharjo District )', Agrokreatif, Jurnal Ilmiah Pengabdian kepada Masyarakat, 4(1), pp. 68-74.

Suminartini, S. and Susilawati, S. (2020) 'Pemberdayaan Masyarakat Melalui Bidang Usaha Home Industry Dalam Meningkatkan Kesejahteraan Masyarakat', Comm-Edu (Community Education Journal), 3(3), p. 226. doi: $\quad 10.22460 /$ commedu.v3i3.3340.

Suprojo, A. and Fithriana, N. (2017) 'Usaha Home Industri Camilan Kripik Jamur Krispy', Jurnal IImu Sosial dan IImu Politik, 6(2), pp. 50-56. 